\title{
ANALISIS KELAYAKAN INVESTASI PEMBUATAN BAGAN APUNG BARU (STUDI PADA NELAYAN BAGAN APUNG DI OESAPA, KOTA KUPANG)
}

\author{
Anthon S. Y. Kerihi \\ Fakultas Ekonomi dan Bisnis Universitas Nusa Cendana \\ anthon@gmail.com
}

\begin{abstract}
Abstact: Estabilishing of a lift net as a business in the field of marine and fisheries, as well as producing fish by following the conditions of the sea and weather which can change and affect production activities so as to provide income that is uncertain and difficult to predict. Therefore, this research was conducted with the aim to find out whether fish production using this lift net can be said to be feasible in the aspects of law, market and marketing, management, technical and operational, economic, social, EIA, and finance. Before recommending to investors, an investment feasibility analysis is needed to determine the level of feasibility. The analysis was carried out with 10-year projections using a pessimistic, moderate and optimistic scenario. Some things that need to be done are, legalizing business activities, designing marketing strategies, knowing technical and operational activities, determining four management functions, knowing the positive economic, social impacts, negative impacts on the environment and determining future sales estimates calculating profit / loss, cash flows, financial feasibility assessment (NPV, IRR, PP and PI) and sensitivity analysis. After the analysis, it was found that this investment is feasible and can be recommended in every scenario and of course the optimistic scenario produces is better level of feasibility compared to other scenarios.
\end{abstract}

Keyword: Feasibility Analysis, Invesment, Lift Net, Fishing Industri.

\section{PENDAHULUAN}

Investasi dalam suatu bisnis yang baru ataupun pengembangan bisnis yang sudah ada, bertujuan untuk memaksimumkan kemakmuran pemilik melalui pengadaan barang dan jasa secara menguntungkan. Proses invetasi meliputi keputusan investasi dan bagaimana mengorganisir kegiatan-kegiatan keputusan investasi. Proses keputusan investasi merupakan proses yang berkesinambungan (going process).

Ada banyak usaha yang dapat dilaksanakan atau usaha yang dapat kita lakukan investasi di negeri ini, terutama di bidang kelautan dan perikanan karena hampir setengah luas negara Indonesia adalah perairan. Alat tangkap yang biasanya dipakai untuk menangkap ikan dalam jumlah besar adalah "KAPAL LAMPARA" atau "BAGAN". Lampara termasuk ke dalam klasifikasi pukat kantong (bag seine net).

Berikut ini jumlah produksi ikan tangkap menurut subsektor dan kabupaten/kota di Provinsi Nusa Tenggara Timur khususnya di pulau Timor pada tahun 2014-2018

Tabel 1

Jumlah Produksi Perikanan Tangkap Menurut Subsektor dan Kabupaten/Kota di Provinsi Nusa Tenggara Timur (Pulau Timor) Pada Tahun 2014-2018

\begin{tabular}{|l|c|c|c|c|c|c|}
\hline \multirow{2}{*}{ Wilayah } & \multicolumn{7}{|c|}{ Produksi Perikanan Tangkap Menurut Subsektor dan } \\
Kabupaten/Kota (Ton) \\
\cline { 2 - 6 }
\end{tabular}




\begin{tabular}{|l|c|c|c|c|c|c|}
\hline $\begin{array}{l}\text { Timur Tengah } \\
\text { Utara }\end{array}$ & 160 & 176 & 178 & 192 & 545 & 1.251 \\
\hline Belu & 1.524 & 1.729 & 1,730 & 1,842 & 2,501 & 9.326 \\
\hline Kota Kupang & 10.014 & 9.965 & 9,291 & 8,811 & 8,433 & 46.514 \\
\hline $\begin{array}{l}\text { Nusa Tenggara } \\
\text { Timur }\end{array}$ & 17.106 & 17.561 & 17,371 & 18,522 & 24,125 & 94.651 \\
\hline
\end{tabular}

Sumber data: https://ntt.bps.go.id/

Dari tabel 1 diatas terlihat bahwa produksi ikan di tiap kabupaten/kota selalu mengalami kenaikan.Kenaikan drastis tiap tahun terjadi di Kabupaten Kupang. Berbeda dengan Kabupaten Kupang, produksi di Kota Kupangtiap tahun mengalami penurunan namun dari tahun 20122016 Kota Kupang lebih banyak memproduksi ikan.
Untuk lebih spesifik, berikut mengenai modal, produksi, nilai penjualan, serta keuntungan yang didapatkan oleh kegiatan penangkapan ikan yang dilakukan pada bagan apung Super Starmilik H. Musliadi dari tahun 2014-2018.

Tabel 2

Modal, Produksi, Nilai Penjualan, dan Profit Pertahun Bagan Apung Tahun 2014-2018

\begin{tabular}{|c|c|c|c|c|}
\hline Tahun & $\begin{array}{c}\text { Modal kerja } \\
\text { (Juta Rupiah) }\end{array}$ & $\begin{array}{c}\text { Produksi } \\
\text { (Ton) }\end{array}$ & $\begin{array}{c}\text { Nilai } \\
\text { Penjualan } \\
\text { (Juta Rupiah) }\end{array}$ & $\begin{array}{c}\text { Profit (Juta } \\
\text { Rupiah) }\end{array}$ \\
\hline 2014 & 412,29 & 8,21 & 597,12 & 184,83 \\
\hline 2015 & 451,76 & 8,92 & 664,87 & 213,11 \\
\hline 2016 & 520,18 & 8,48 & 692,2 & 172,02 \\
\hline 2017 & 508,09 & 9,13 & 730,7 & 222,61 \\
\hline 2018 & 591,12 & 9,75 & 779,7 & 188,58 \\
\hline Total & $\mathbf{2 4 3 2 , 1 8}$ & $\mathbf{4 4 , 4 9}$ & $\mathbf{3 4 6 4 , 5 9}$ & $\mathbf{7 9 1 , 5 7}$ \\
\hline
\end{tabular}

Sumber: Data Keuangan Bagan H.Musliadi (data diolah)

Setiap tahun modal yang dikeluarkan terus mengalami peningkatan diikuti dengan jumlah produksi walaupun pada tahun 2017 produksi mengalamipenurunan, namun pendapatan yang diterima meningkat. Hal tersebut dikarenakan harga ikan pada tahun tersebut meningkat diikuti hasil produksi yang meningkat pula.
Lama operasi (trip) alat tangkap bagan apung setiap bulan bervariasi mulai dari 20-31 hari sehingga menghasilkan pendapatannya naik turun. Gambaran trip dan pendapatan nelayan bagan apung sebagai berikut: 


\section{Gambar 1}

\section{Grafik Jumlah Trip dan Pendapatan}

Tahun 2019

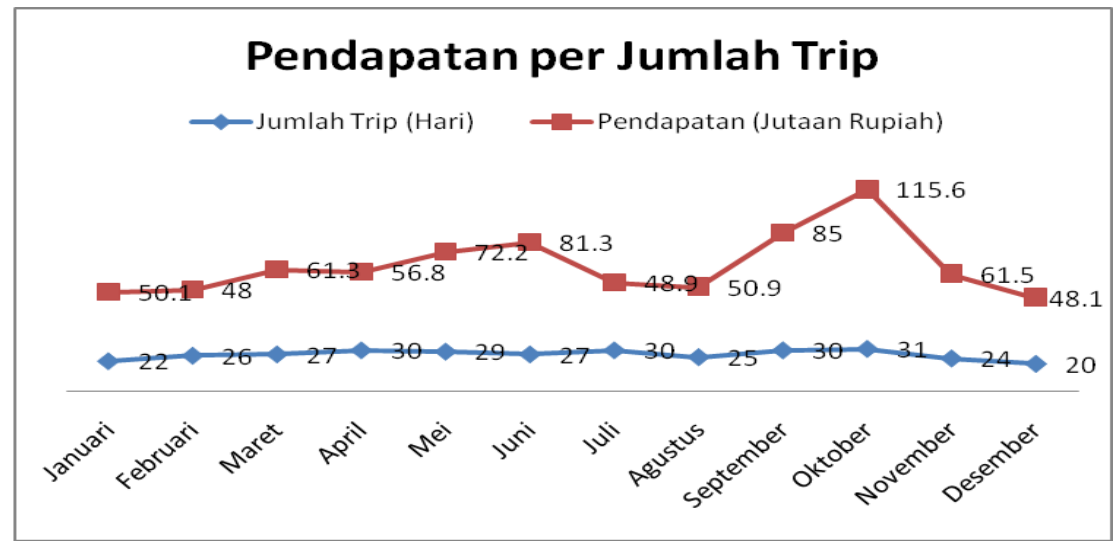

Gambar di atas, menunjukan bahwa bulan terbaik dalam melakukan trip adalah SeptemberNovember, dan diikuti oleh bulan mei. Para nelayan setiap hari terus pergi ke laut untuk menangkap ikan kecuali, saat cuaca betul-betul buruk dilaut, saat bagan mengalami kerusakan sehingga tidak bisa beroperasi dan pada saat hari raya besar, seperti lebaran dan natal.

Di saat yang tidak menentu seperti ini, investor akan tetap mencari peluang investasi yang menentu. Oleh karena itu penting untuk dilakukan penelitian di bidang teknis dan ekonomi. Tujuannya adalah mengetauhi apakah penangkapan ikan menggunakan bagan ini dapat dikatakan layak pada aspek hukum, pasar dan pemasaran, manajemen, teknis dan operasi, ekonomi, sosial, AMDAL, dan keuangan serta apakahbisa menghasilkan tingkat pengembalian yang diharapkan di masa mendatang. Namun untuk bisa mengetahui hal tersebut harus dilakukan analisis kelayakan investasi. Analisis kelayakan investasi dapat dipahami sebagai tindakan yang dilakukan untuk mengetahui prospek dari suatu proyek investasi maka harus menganlisis besarnya biaya, keuntungan, PP (payback Period), NPV (Net Present Value), IRR (Internal rate of Return) dan PI (Profitability Index) yang mendasari pengambilan keputusan. Adapun masalah dalam penelitian ini adalah Bagaimanakah tingkat kelayakan investasi usaha pembuatan bagan apung baru di Oesapa?"

\section{KAJIAN PUSTAKA}

\section{Investasi}

Investasi dapat diartikan sebagai komitmen untuk menanamkan sejumlah dana pada saat ini dengan tujuan memperoleh keuangan di masa mendatang. Investasi merupakan komitmen untuk mengorbankan konsumsi sekarang (sacrifice current consumption) dengan tujuan memperbesar konsumsi di masa mendatang.

Menurut Tandelilin (2010:8) ada beberapa alasan mengapa seseorang melakukan investasi, antara lain :

1. Untuk mendapatkan kehidupan yang lebih layak di masa depan

2. Mengurangi resiko inflasi

3. Dorongan untuk menghemat pajak

Menurut Sunariyah (2004:4) investasi dalam arti luas terdiri dari dua bagian utama yaitu:

1. Investasi dalam bentuk aktiva rill (real asset)

2. Investasi dalam bentuk surat-surat berharga (financial asset)

Menurut Fahmi dan Hadi (2009:7) dalam aktivitasnya investasi pada umumnya dikenal ada dua bentuk, yaitu: Real investment (Investasi Nyata) yakni )secara umum melibatkan aset berwujud seperti tanah, mesin-mesin atau pabrik. 1). Financial investment (Investasi Keuangan), dan 2) Investasi keuangan (financial investment) melibatkan kontrak tertulis, seperti saham biasa (common stock) dan obligasi (bond).Perbedaan antara investasi pada real investment dan financial investment adalah tingkat likuiditas dari kedua investasi tersebut.Investasi pada real investment relatif lebih sulit untuk dicairkan karena terbentur pada komitmen jangka panjang antara investor dengan perusahaan.Sementara investasi pada financial investment lebih mudah dicairkan karena dapat diperjual belikan tanpa terikat waktu.

Keputusan investasi dapat dilakukan oleh individuatau suatu tempat entitas yang mempunyai 
kelebihan dana. Menurut Sunariyah (2004:4) investasi dalam arti luas terdiri dari dua bagian utama yaitu: 1) Investasi dalam bentuk aktiva rill (real asset) berupa aktiva berwujud seperti emas, perak, intan, barang-barang seni dan real estate. 2) Investasi dalam bentuk surat-surat berharga (financial asset) berupa surat-surat berharga yang pada dasarnya merupakan klaim atas aktiva rill yang di kuasai oleh entitas. Pemilihan aktiva financial dalam rangka investasi pada sebuah entitas dapat di lakukan dengan dua cara: a).

\section{Studi kelayakan Bisnis}

Kasmir \& Jakfar (2012 : 6), Studi Kelayakan Bisnis (SKB) adalah suatu kegiatan yang mempelajari secara mendalam tentang suatu usaha atau bisnis yang akan dijalankan, dalam rangka menentukan layak atau tidak usaha tersebut dijalankan. Menurut Kasmir dan Jakfar (2006: 12) paling tidak ada lima tujuan mengapa sebelum suatu usaha atau proyek dijalankan perlu dilakukan studi kelayakan, yaitu: Menghindari Risiko Kerugian, Memudahkan Perencanaan, Memudahkan Pelaksanaan Pekerjaan, Memudahkan Pengawasan, Memudahkan Pengendalian.

Jati (2008: 11) maksud SKB disini adalah untuk menganalisa terhadap suatu bisnis/proyek tertentu, baik bisnis/proyek yang akan dilaksanakan, sedang dan selesai dilaksanakan untuk bahan perbaikan dan penilaian pelaksanaan bisnis/proyek tersebut.

Menurut Kasmir \& Jakfar (2012 :24), bahwa aspek-aspek kelayakan investasi sebagai berikut:

\section{Aspek Hukum}

Untuk memulai studi kelayakan suatu usaha pada umumnya dimulai dari aspek hukum. Tujuan dari aspek hukum adalah untuk meneliti keabsahan, kesempurnaan, dan keaslian dari dokumen-dokumen yang dimiliki.

\section{Aspek Pasar dan Pemasaran}

Pasar sangat menentukan kelayakan suatu bisnis artinya, besar kecilnya potensi pasar yang meminta barang dan jasa menjadi pemicu suatu rencana bisnis direalisasikan. Segmen mana yang akan dilayani dan berapa bagian pasar yang dikuasai dari produk yang ditawarkan merupakan kajian lain dari aspek pasar.

\section{Aspek Teknis/Operasi}

Investasi langsung (direct investment). Investasi langsung dapat diartikan sebagai suatu pemilikan surat-surat berharga secara langsung dalam suatu entitas yang secara resmi telah go publik dengan harapan akan mendapatkan keuntungan berupa penghasilan dividen dan capital gain.dan b) Investasi tidak langsung (indirect investment). Investasi tidak langsung (indirect investment) terjadi bilamana surat-surat berharga yang dimiliki diperdagangkan kembali oleh perusahaan investasi (investment company).

Dalam aspek ini yang akan diteliti mengenai lokasi usaha, kantor pusat, pabrik cabang atau gudang. Kemudian penentuan layout gedung, mesin dan peralatan serta layout ruangan sampai kepada perluasan usaha selanjutnya.

\section{Aspek Manajemen/Organisasi}

Yang dinilai dari aspek ini adalah dari pengelolah usaha dan struktur organisasi yang ada. Usaha yang dijalankan akan berhasil jika dijalankan oleh orang-orang profesional, mulai dari merencanakan, melaksanakan, sampai dengan mengendalikan jika terjadi penyimpangan.

\section{Aspek Ekonomi dan Sosial}

Penelitian dalam aspek ini adalah untuk melihat seberapa besar pengaruh yang ditimbulkan jika usaha ini dijalankan. Pengaruh ini terutama terhadap ekonomi secara luas serta dampak sosialnya terhadap keseluruhan.

\section{Aspek Amdal}

Merupakan analisis yang paling dibutuhkan saat ini, karena setiap usaha yang dijalankan akan sangat besar dampaknya terhadap lingkungan di sekitar, baik terhadap darat, air, dan udara yang pada akhirnya akan berdampak kepada kehidupan manusia, binatang, dan tumbuhan yang ada disekitarnya.

\section{Aspek Keuangan}

Penelitian ini meliputi seberapa lama investasi yang ditanamkan dapat kembali. Kemudian dari mana saja sumber pembiayaan tersebut dana bagaimana tingkat suku bunga yang berlaku, sehingga dihitung dengan formula penilaian investasi sangat menguntungkan. Metode penilaian yang akan digunakan nantinya dalah Payback periode, Net Present Value, Internal Rate of Return, Profitability Index dan Average Rate of Return serta dengan rasio keuangan lainnya.

1. Penelitian ini mengkaji tentang analisis kelayakan investasi pada bagan baru, dengan menggunakan data yang diperoleh dari bagan yang 
dijalankan oleh milik $H$. Musliadi. Bagan tersebutakan di operasikan di laut Oesapa, kelurahan Oesapa, Kecamatan Kelapa Lima, Kota Kupang, Nusa Tenggara Timur. Data kualitatif tidak dapat diukur secara langsung menggunakan angka atau bilangan tetapi menggunakan informasi, keterangan, laporan ataupun profil usaha. Dan data kantitatif adalah data yang dikumpulkan dalam bentuk angka-angka, seperti jumlah pendapatan pertahun, laba bersih pertahun, dan pengeluaran dalam setahun.

Penelitian ini akan dikaji atau dianalisis dari beberapa aspek yakni: 1) Aspek Hukum. Kajian ini berkaitan dengan legalitas dari rencana bisnis, seperti bentuk badan hukum, keabsahan akte pendirian, dan izin-izin yang diperlukan untuk melakukan bisnis di sektor tertentu. 2) Aspek Manajemenen. Aspek ini yang dimulai adalah tugas dan fungsi pokok yang harus dilaksanakan untuk menghasilkan dan menyediakan barang/jasa , struktur organisasi yang menggambarkan pembagian tugas, distribusi wewenang, jabatan kunci dalam organisasi. Sedangkan manajemen mencakup: perencanaan proyek/bisnis, pelaksanaan, dan pengendalian untuk mempermudah pencapaian tujuan yang diharapkan. 3) Aspek Pasar dan Pemasaran. Metode yang digunakan untuk menilai aspek ini 1) Net Present Value

Cara perhitungan menurut Umar (2003) NPV adalah sebagai berikut:

$$
N P V=\sum_{t=1}^{n} \frac{C f t}{1+k}-I o
$$

NPV : Net Present Value, Cft : Aliran kas tahun pertama, Io : Investasi awal tahun, dan K : Tingkat Bunga (Discount rate)

Kriteria : NPV $>0=$ Usaha Layak atau NPV $<0=$ Usaha Tidak Layak 2) IRR

Adapun rumus menurut Kasmur dan Jakfar (2012:105) untuk menghitung IRR adalah sebagai berikut:

$$
I R R=i_{1}+\frac{N P V_{1}}{N P V_{1}-N P V_{2}} x\left(i_{2}-i_{1}\right)
$$

IRR :Internal Rate of Return, $\mathrm{i}_{1}$ : Tingkat bunga pertama, $\mathrm{i}_{2}$ : Tingkat Bunga Kedua, $\mathrm{NPV}_{1}$ : NPV pada tingkat bunga pertama, $\mathrm{NPV}_{2}:$ NPV pada tingkat bunga kedua,

Kriteria: IRR > discount rate $=$ Usaha Layak atau IRR $<$ discount rate $=$ Usaha Tidak Layak.

3) Pa yback Period

Menurut Sucipto (2011:76) PP dapat dirumuskan sebagai berikut:

1. Jika aliran kas per tahun jumlahnya sama

$$
\text { Payback Period }(\mathrm{PP})=\frac{\text { total investment }}{\text { cash flow }} \times 1 \text { tahun }
$$


2. Jika aliran kas per tahun jumlahnya tidak sama

$$
\text { Payback Period }(\mathrm{PP})=\mathrm{n}+\frac{b-c}{d-c}
$$

Keterangan: $\mathrm{n}$ : Tahun terakhir dimana cash inflow belum menutupi nilai investasi, b : Nilai investasi, c : Komulatif cash inflow pada tahun ke-t, d : Jumlah kumulatif cash inflow pada tahun ke-t

Kriteria: $\mathrm{PP}>$ Periode maksimum investasi $=$ Usaha Tidak Layak, $\mathrm{PP}<$ Periode maksimum investasi $=$ Usaha Layak

4) Profitability Index

Rumus perhitungan PI menurut Kasmir dan Jakfar (2012:163) adalah sebagai berikut:

$$
P I=\frac{\sum P V \text { cash } f l o w}{\sum P V \text { investasi }}
$$

Kriteria:

$$
\begin{aligned}
& \text { PI }>0=\text { Usaha Layak } \\
& \text { PI }<0=\text { Usaha Tidak Layak }
\end{aligned}
$$

1. Analisis Sensitivitas

Dalam penelitian ini dilakukan analisis sensitivitas dengan metode switching value untuk melihat sejauh mana perubahan variabel dapat mengakibatkan nila $N P V$ sama dengan nol dan nilai $I R R$.

\section{HASIL DAN PEMBAHASAN}

\section{Profil Nelayan Bagan Apung}

\begin{tabular}{|c|c|c|c|c|c|}
\hline \multirow{2}{*}{ Tahun } & \multicolumn{4}{|c|}{ Nelayan } & \multirow{2}{*}{ Jumlah } \\
\cline { 2 - 5 } & Bagan Apung & $\%$ & Bagan Tancap & $\%$ & \\
\hline 2015 & 12 & $44,4 \%$ & 15 & $55,6 \%$ & 27 \\
\hline 2016 & 13 & $43,3 \%$ & 17 & $56,7 \%$ & 30 \\
\hline 2017 & 13 & $46,1 \%$ & 16 & $53,9 \%$ & 29 \\
\hline 2018 & 14 & $43,7 \%$ & 18 & $56,3 \%$ & 32 \\
\hline 2019 & 12 & $40 \%$ & 18 & $60 \%$ & 30 \\
\hline
\end{tabular}

Setiap tahun jumlah bagan tancap lebih tahun 2016 dan 2018. Pada tahun 2016 bagan banyak daripada bagan apung, dikarenakan modal untuk membuat bagan tancap lebih sedikit dari membuat bagan apung. Jumlah bagan apung setiap apung tetap pada angka 13 dan pada tahun 2018, ada dua bagan apung berhenti beroperasi karena rusak diterjang gelombang laut. tahun selalu mengalami peningkatan kecuali pada

\section{Umur Rata-Rata Nelayan Bagan Apung}

\begin{tabular}{|c|l|c|c|}
\hline No & Umur & Jumlah & Persen \\
\hline 1 & $>50$ Tahun & 5 & $5,56 \%$ \\
\hline 2 & 40-50 Tahun & 8 & $8,89 \%$ \\
\hline 3 & $30-40$ Tahun & 17 & $18,89 \%$ \\
\hline 4 & 20-30 Tahun & 31 & $34,44 \%$ \\
\hline 5 & 15- 20 Tahun & 29 & $32,22 \%$ \\
\hline \multicolumn{2}{|c|}{ Jumlah } & $\mathbf{9 0}$ & $\mathbf{1 0 0 \%}$ \\
\hline
\end{tabular}


Umur rata-rata nelayan bagan apung di Oesapa adalah 28 tahun. Umur minimal nelayan bagan apung adalah 15 tahun, sedangkan umur maksimal adalah 53 tahun. Umumnya umur nelayan bagan apung berkisar antara 20-30 tahun.

\section{Tingkat Pendidikan Nelayan Bagan Apung}

\begin{tabular}{|c|l|c|c|}
\hline No & Tingkat Pendidikan & Jumlah & Persen \\
\hline 1 & Tidak Tamat SD & 11 & $12,22 \%$ \\
\hline 2 & Tamat SD & 23 & $25,56 \%$ \\
\hline 3 & Tamat SMP & 41 & $45,56 \%$ \\
\hline 4 & Tamat SMA & 15 & $16,67 \%$ \\
\hline \multicolumn{2}{|c|}{ Jumlah } & $\mathbf{9 0}$ & $\mathbf{1 0 0 \%}$ \\
\hline
\end{tabular}

Tingkat pendidikan nelayan bagan apung tergolong rendah, karena pendidikan yang ditempuh nelayan rata-rata hanya sebatas tamat sekolah menengah pertama (SMP). Ini artinya nelayan tidak bisa menerima pembaruan dan teknologi yang akan terus berkembang mengikuti zaman.

\section{Aspek Hukum}

Dalam mendirikan usaha, hal-hal yang akan dibahas adalah:

1. Melakukan rapat dan pengurusan tentang pengendalian perusahaan

a. Nama dan bentuk usaha yang akan didirikan dan tempat kedudukannya.

b. Jangka waktu pendirian

c. Maksud dan tujuan penjelasan jenis usaha yang akan dijalankan

d. Kepengurusan, tugas, dan wewenang dan hal lainnya yang merupakan standar hukum pendirian perusahaan

2. Mengesahkan hasil rapat pada notaris pendirian usaha

3. Mendaftarkan usaha yang dijalan berupa alat tangkap yang di pakai pada Dinas Kelautan dan Perikanan di kota yang bersangkutan

4. Melakukan penyetoran modal dan penyertaan pembentukan sebuah usaha dan melakukan pengabsahan oleh departemen kehakiman

5. Berdasarkan akte pendirian perusahaan, pihak pengelola dapat segera mengurus NPWP, SIUP, dan dokumen pendukung untuk keperluan melakukan usaha.

Aspek Pasar dan Pemasaran

Metode yang digunakan untuk menganalisis kelayakan investasi dalam penelitian ini adalah marketing mix atau bauran pemasaran.

a. Product (Produk). Hasil penangkapan ikan dapat berupa ikan kecil maupun besar, ikan yang sering masuk dalam jaring bagan adalah ikan teri, serdin, japuh, selar, paperek, kerotkerot, cumi-cumi, sotong, layur, dan kembung, dan masih banyak lagi. Ikan yang dijual nantinya merupakan produk yang berkualitas dan segar karena ikan akan langsung dijual pada hari tersebut atau pada keesokan paginya.

b. Price (Harga). Harga jual ikan di pasar cukup bervariasi tergantung jenis ikan, kualitas ikan, gizi serta rasa yang ditawarkan dari jenis ikan tersebut. Harga jual ikan adalah Rp 300.000/ember. Namun harga tersebut masih bisa ditawarkan oleh pembeli. Ember yang digunakan dalam takaran perhitungan harga jual adalah ember cat dengan ukuran tinggi $37,5 \mathrm{~cm}$, diameter $30 \mathrm{~cm}$ dan volume 20lt atau 25KG.

c. Place (Tempat). Ada dua tempat transaksi penjualan ikan tangkap bagan apung. Tempat pertama adalah di bagan, saat distributor (distributor) akan mengambil ikan. tempat kedua adalah pasar (pasar Oesapa dan Oeba) yang menjadi tempat transaksi distributor dengan konsumen maupun pengecer.

d. Promotion (Promosi). Promosi yang dilakukan adalah promosi tradisional, yaitu promosi dari mulut ke mulut (Word of Mouth) dengan memberikan rekomendasi kepada warga sekitar dengan harapan warga tersebut juga memberikan rekomendasi kepada pihak-pihak lainnya.

\section{Aspek Teknis dan Operasi}

Saat tiba di bagan para nelayan akan melakukan persiapan untuk mesin, jaring dan lampu. Jika hari sudah mulai gelap maka nelayan siap menurunkan jaring, setelah jaring menyentuh dasar, maka lampu dinyalakan. Setelah itu, nelayan akan menunggu hingga beberapa jam untuk menunggu ikan berkumpul di permukaan. Jika ikan telah berkumpul maka lampu akan dimatikan dan jaring 
akan mulai diangkat. Hal itu akan terus dilakukan hingga langit telah terang.

Jika ikan sudah terkumpul, juragan akan menghubungi distributor agar datang ke bagan mengambil ikan untuk distributor jual ke pasar. Setelah distributor menjual ikan maka distributor akan mengantar hasil jualan ke nelayan dan membagi hasil jualan, biasanya nelayan membagi hasil $80 \%$ untuk diri sendiri dan $20 \%$ distributor.

\section{Aspek Manajemen}

Analisis aspek manajemen yang dilakukan di penelitian ini diantaranya adalah:

1. Perencanaan (Planning)

Dalam proses ini ditentukan tentang apa yang harus dilakukan, kapan, dan bagaimana melakukannya serta dengan cara apa hal tersebut dilakukan yaitu, perencanaan usaha (1) jenis pekerjaan. Jenis pekerjaan yang dilakukan adalah mepersiapkan dan melengkapi kebutuhan dalam berproduksi ikan dengan bagan apung. (2) waktu penyelesaian. Waktu penyelesaian yang diharapkan adalah pada awal tahun 2020. (3) anggaran. Anggaran dan perincian perencanaan usaha dapat dilihat pada aspek keuangan.

2. Pengorganisasian (Organizing)

Usaha bagan apung merupakan usaha yang tidak memiliki struktur organisasi yang resmi karena semua pekerjaan diperintahkan langsung dari atasan ke bawahan.Namun untuk urusan pekerjaannya sudah terstruktur.

3. Pelaksanaan (actuating)

Untuk pelaksanaan tugas dan pekerjaan bisa dilihat pada alur pengoperasian bagan. Salah satu tugas atau pekerjaan seperti jika akan menarik waring, dibagi tempat untuk menarik pada alat derek yang berbeda-beda sehingga lebih cepat dalam menarik waring tersebut

4. Pengawasan (controlling)

Pengawasan harus dilakukan pada saat perencanaan usaha dan saat pelaksanaan Usaha. Pengawasan pada saat perencanaan usaha seperti mengerjakan semua pekerjaan sesuai penjadwalan agar pekerjaan sesuai tepat waktu. Pengawasan pada saat pelaksanaan usahaseperti juragan bagan mengawasi kegiatan pekerjaan bawahannya dan memastikan tidak tertiduran karena pekerjaan yang dilakukan pada malam hari atau pada saat jam tidur seharusnya.

\section{Aspek Ekonomi dan Sosial}

Membuat sebuah bagan baru, artinya dapat memberikan dampak pada perekonomian negara dan dampak bagi masyarakat di oesapa, antara lain:

1. Meningkatkan penghasilan

2. Meningkatkan penerimaan negara

Pada konstruksi bagan, terdapat tempat seperti rumah-rumahan, fungsinya adalah sebagai tempat untuk berteduh jika hujan datang, memasak, makan dan minum serta untuk beribadah. Selain itu dampak sosial dari usaha bagan apung adalah:

1. Membuka lowongan pekerjaan

2. Perubahan tingkat pengetahun pekerja

3. Meningkatkan kontribusi hasil penangkapan ikan.

\section{Aspek Dampak Lingkungan}

Untuk produksi ikan pada bagan apung hanya dengan menggunakan cahaya dari lampu dan tidak menggunakan umpan berbahaya bagi laut dan ikan dan memiliki penampungan untuk pembuangan sisa solar sehingga tidak merusak ekosistem di lautan.

\section{Aspek Keuangan \\ Kebutuhan Dana}

Kebutuhan dana dan biaya penyusutan dan amortisasi 


\begin{tabular}{|c|c|c|c|c|c|}
\hline No & $\begin{array}{c}\text { Jenis Mesin dan } \\
\text { Peralatan }\end{array}$ & $\begin{array}{l}\text { Jumlah } \\
\text { Satuan }\end{array}$ & $\begin{array}{l}\text { Harga Beli } \\
\text { (Rp) }\end{array}$ & $\begin{array}{c}\text { Umu } \\
\text { Ekonomi } \\
\text { s (Thn) }\end{array}$ & $\begin{array}{c}\text { Penyusutan } \\
\text { dan } \\
\text { Amortisasi }\end{array}$ \\
\hline & Penyusutan & & & & \\
\hline 1 & Bagan & 1 & 300.000 .000 & 20 & 15.000 .000 \\
\hline 2 & Perahu & 1 & 80.000 .000 & 20 & 4.000 .000 \\
\hline 3 & Mesin Bagan & 5 & 250.000 .000 & 10 & 25.000 .000 \\
\hline 4 & Mesin Perahu & 3 & 120.000 .000 & 10 & 12.000 .000 \\
\hline 5 & Lampu & 70 & 14.000 .000 & 2 & 5.600 .000 \\
\hline 6 & Waring & 50 & 37.500 .000 & 2 & 15.000 .000 \\
\hline 7 & Travo & 70 & 21.000 .000 & 2 & 8.400 .000 \\
\hline 8 & Tali Tambang & 5 & 5.000 .000 & 2 & 2.000 .000 \\
\hline 10 & Frezeer & 1 & 2.000 .000 & 3 & 600.000 \\
\hline 12 & Kompor Gas & 1 & 500.000 & 2 & 250.000 \\
\hline \multirow[t]{2}{*}{12} & Inventaris Lainnya & & 2.500 .000 & 2 & 1.250 .000 \\
\hline & Amortisasi & & & & \\
\hline 13 & Biaya Pra Investasi & $\mathbf{1}$ & 6.850 .000 & & 685.000 \\
\hline \multicolumn{3}{|c|}{ Jumlah } & & & 89.785 .000 \\
\hline
\end{tabular}


Modal yang dikeluarkan adalah sebesar Rp 1.000.000.000 dengan menggunakan modal sendiri sebesar $\mathrm{Rp} 500.000 .000$ dan modal pinjaman bank $\mathrm{Rp}$ 500.000.00. Biaya umum untuk kebutuhan investasi adala sebesar Rp 839.350.000 dan sisanya akan digunakan pada biaya modal kerja/operasional.

\begin{tabular}{|c|c|c|c|c|c|c|c|c|}
\hline \multicolumn{9}{|c|}{ yan Modal Kerja/Biaya $\mathrm{O}$} \\
\hline No & Jenis Biaya & \multicolumn{2}{|c|}{$\begin{array}{l}\text { Jumlah } \\
\text { Satuan }\end{array}$} & \multicolumn{2}{|c|}{ Harga Satuan } & \multicolumn{2}{|c|}{$\begin{array}{c}\text { Proyeksi Tahun } \\
\text { Pertama }\end{array}$} & Spesifikasi \\
\hline \multirow{3}{*}{1} & Biaya Bahan Baku Langsung & & & & & & & \\
\hline & Bahan Bakar (Solar) & 12840 & Liter & $\mathrm{Rp}$ & 9.800 & $\mathrm{Rp}$ & 125.832 .000 & Rata-rata 40 ltr/hari, 26 hari kerja, 12 bulan \\
\hline & Umpan Mancing & 321 & $\mathrm{Kg}$ & $\mathrm{Rp}$ & 20.000 & $\mathrm{Rp}$ & 6.420 .000 & Rata-rata $1 \mathrm{Kg} /$ hari, 26 hari kerja, 12 bulan \\
\hline \multirow[t]{3}{*}{2} & Biaya Tenaga Kerja & & & & & & & \\
\hline & Tenaga kerja di bagan & 7 & Orang & $\mathrm{Rp}$ & 2.500 .000 & $\mathrm{Rp}$ & 240.000 .000 & 6 gaji awak kapal 2,5jt dan Juragan $5 \mathrm{jt}$ \\
\hline & Tenaga kerja di darat & 1 & Orang & $\mathrm{Rp}$ & 500.000 & $\mathrm{Rp}$ & 6.000 .000 & dibutuhkan saat perahu sandar dan siap berangkat \\
\hline \multirow[t]{3}{*}{3} & Biaya Overhead Pabrik & & & & & & & \\
\hline & Makan karyawan & & & & & $\mathrm{Rp}$ & 8.418 .000 & Berupa beras, minyak, air minum, garam, dll \\
\hline & Rokok & 321 & Slop & $\mathrm{Rp}$ & 150.000 & $\mathrm{Rp}$ & 48.150 .000 & 1 bungkus rokok $/ 1$ orang, sisanya dibagi rata di darat \\
\hline \multirow[t]{3}{*}{4} & Biaya reparasi dan pemeliharaan & & & & & & & \\
\hline & $\begin{array}{l}\text { Perawatan dan pemeliharaan } \\
\text { mesin }\end{array}$ & 8 & Mesin & $\mathrm{Rp}$ & 500.000 & $\mathrm{Rp}$ & 120.000 .000 & $\begin{array}{l}\text { Tiap } 1 \text { bulan } 2 \text { mesin dilakukan periksaan dan } \\
\text { perawatan }\end{array}$ \\
\hline & $\begin{array}{l}\text { Perawatan dan pemeliharaan } \\
\text { bagan perahu }\end{array}$ & 2 & Unit & $\mathrm{Rp}$ & 1.000 .000 & $\mathrm{Rp}$ & 24.000 .000 & Tiap 1 bulan dilakukan pemeriksaan dan perawatan \\
\hline 5 & Biaya Administrasi dan Penjualan & & & & & $\mathrm{Rp}$ & 12.300 .000 & Bonus 5\% dari upah \\
\hline \multicolumn{2}{|r|}{ Jumlah } & & & & & $\mathbf{R p}$ & 591.120.000 & \\
\hline
\end{tabular}

Pengoperasian bagan apung, memerlukan biaya-biaya yang akan menunjang kegiatan operasai bagan. Biaya-biaya yang dikeluarkan berupa biaya harian, minggan, hingga bulanan. Asumsi-asumsi biaya ini tidak bisa di prediksi berdasarkan jumlah produksi karena produksi ikan tidak bisa diproduksi dengan tepat mengingat cuaca dan keadaan alam pada malam hari.

\section{Laporan Laba/Rugi}

Pesimis: Penjualan naik 1\% dan biaya tetap (000) 


\begin{tabular}{|c|c|c|c|c|c|c|c|c|c|c|c|c|}
\hline TAHUN & & 1 & 2 & 3 & 4 & 5 & 6 & 7 & 8 & 9 & & 10 \\
\hline TOTAL PENJUALAN & $\mathrm{Rp}$ & 779,724 & Rp 787,521 & Rp 795,396 & Rp 803,350 & $\operatorname{Rp~} 811,384$ & Rp 819,498 & \begin{tabular}{|l|} 
Rp 827,693 \\
\end{tabular} & Rp 835,970 & Rp 844,329 & $\mathrm{Rp}$ & 852,773 \\
\hline $\begin{array}{l}\text { BIAYA OPERASI } \\
\text { 1. BAHAN BAKU }\end{array}$ & & & & & & & & & & & & \\
\hline Bahan Bakar (Solar) & $\mathrm{Rp}$ & 125,832 & Rp 125,832 & Rp 125,832 & Rp 125,832 & Rp 125,832 & Rp 125,832 & Rp 125,832 & Rp 125,832 & Rp 125,832 & $\mathrm{Rp}$ & 125,832 \\
\hline $\begin{array}{c}\text { Umpan Mancing } \\
\text { 2. OVERHEAD PABRIK }\end{array}$ & $\mathrm{Rp}$ & 6,420 & $\mathrm{Rp} \quad 6,420$ & $\mathrm{Rp} \quad 6,420$ & $\mathrm{Rp} \quad 6,420$ & $\mathrm{Rp} \quad 6,420$ & Rp $\quad 6,420$ & $\mathrm{Rp} \quad 6,420$ & $\mathrm{Rp} \quad 6,420$ & $\mathrm{Rp} \quad 6,420$ & $\mathrm{Rp}$ & 6,420 \\
\hline Makan-minum & $\mathrm{Rp}$ & 8,418 & $\mathrm{Rp} \quad 8,418$ & $\mathrm{Rp} \quad 8,418$ & $\mathrm{Rp} \quad 8,418$ & $\mathrm{Rp} \quad 8,418$ & $\mathrm{Rp} \quad 8,418$ & $\operatorname{Rp} \quad 8,418$ & Rp $\quad 8,418$ & Rp $\quad 8,418$ & $\mathrm{Rp}$ & 8,418 \\
\hline Rokok & $\mathrm{Rp}$ & 48,150 & Rp 48,150 & Rp 48,150 & Rp 48,150 & $\operatorname{Rp} 48,150$ & Rp 48,150 & Rp 48,150 & Rp 48,150 & Rp 48,150 & $\mathrm{Rp}$ & 48,150 \\
\hline 3. REPARASI \& PERAWATAN AKTIVA & & & & & & & & & & & & \\
\hline Pemeliharaan Mesin & $\mathrm{Rp}$ & 120,000 & Rp 120,000 & Rp 120,000 & Rp 120,000 & Rp 120,000 & Rp 120,000 & Rp 120,000 & Rp 120,000 & Rp 120,000 & $\mathrm{Rp}$ & 120,000 \\
\hline Pemeliharaan Bagan dan Perahu & $\mathrm{Rp}$ & 24,000 & Rp 24,000 & Rp 24,000 & Rp 24,000 & Rp 24,000 & Rp 24,000 & Rp 24,000 & Rp 24,000 & Rp 24,000 & $\mathrm{Rp}$ & 24,000 \\
\hline Jumlah Biaya Operasi & $\mathrm{Rp}$ & 332,820 & Rp 332,820 & Rp 332,820 & Rp 332,820 & Rp 332,820 & Rp 332,820 & Rp 332,820 & Rp 332,820 & Rp 332,820 & $\mathrm{Rp}$ & 332,820 \\
\hline 4. BIAYA TENAGA KERJA & & & & & & & & & & & & \\
\hline Tenaga Tetap & $\mathrm{Rp}$ & 240,000 & Rp 240,000 & Rp 240,000 & Rp 240,000 & Rp 240,000 & Rp 240,000 & Rp 240,000 & Rp 240,000 & Rp 240,000 & $\mathrm{Rp}$ & 240,000 \\
\hline Tenaga Tidak tetap & $\mathrm{Rp}$ & 6,000 & Rp $\quad 6,000$ & Rp $\quad 6,000$ & Rp $\quad 6,000$ & Rp $\quad 6,000$ & Rp $\quad 6,000$ & Rp $\quad 6,000$ & $\mathrm{Rp} \quad 6,000$ & $\mathrm{Rp} \quad 6,000$ & $\mathrm{Rp}$ & 6,000 \\
\hline 5. BIAYA ADMINISTRSI \& PENJUALAN & $\mathrm{Rp}$ & 12,300 & Rp 12,300 & Rp 12,300 & Rp $\quad 12,300$ & Rp $\quad 12,300$ & $\mathrm{Rp} \quad 12,300$ & Rp 12,300 & Rp 12,300 & Rp 12,300 & $\mathrm{Rp}$ & 12,300 \\
\hline TOTAL BIAYA OPERASI & $\mathrm{Rp}$ & 591,120 & Rp 591,120 & Rp 591,120 & Rp 591,120 & Rp 591,120 & Rp 591,120 & Rp 591,120 & Rp 591,120 & Rp 591,120 & $\mathrm{Rp}$ & 591,120 \\
\hline LABA KOTOR & $\mathrm{Rp}$ & 188,604 & Rp 196,401 & Rp 204,276 & $\operatorname{Rp} 212,230$ & $\operatorname{Rp} 220,264$ & $\operatorname{Rp} 228,378$ & Rp 236,573 & Rp 244,850 & Rp 253,209 & $\mathrm{Rp}$ & 261,653 \\
\hline Biaya Peny. Dan Amortisasi & $\mathrm{Rp}$ & 89,785 & \begin{tabular}{|ll}
$\operatorname{Rp} \quad 89,785$ \\
\end{tabular} & \begin{tabular}{|l|}
$\operatorname{Rp} \quad 89,785$ \\
\end{tabular} & 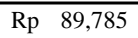 & 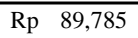 & $\begin{array}{|ll|}\text { Rp } & 89,785 \\
\end{array}$ & \begin{tabular}{|ll}
$\operatorname{Rp} \quad 89,785$ \\
\end{tabular} & Rp 89,785 & Rp 89,785 & $\overrightarrow{\mathrm{Rp}}$ & 89,785 \\
\hline Biaya Bunga & $\mathrm{Rp}$ & 30,000 & Rp $\quad 27,724$ & Rp 25,311 & Rp $\quad 22,754$ & Rp 20,043 & $\mathrm{Rp} \quad 17,170$ & Rp 14,124 & Rp $\quad 10,895$ & 7,473 & $\mathrm{Rp}$ & 3,845 \\
\hline LABA SEBELUM PAJAK & $\mathrm{Rp}$ & 68,819 & $\begin{array}{|ll|}\operatorname{Rp} & 78,892 \\
\end{array}$ & \begin{tabular}{|ll}
$\operatorname{Rp} \quad 89,180$ \\
\end{tabular} & \begin{tabular}{|l|}
$\operatorname{Rp} \quad 99,691$ \\
\end{tabular} & Rp 110,436 & \begin{tabular}{|l|} 
Rp 121,423 \\
\end{tabular} & \begin{tabular}{|l|}
$\operatorname{Rp} 132,664$ \\
\end{tabular} & Rp 144,169 & Rp 155,951 & $\mathrm{Rp}$ & 168,022 \\
\hline \begin{tabular}{|l|} 
Ak. Laba Terkena Pajak \\
\end{tabular} & $\mathrm{Rp}$ & 68,819 & \begin{tabular}{|l|l|} 
Rp 78,892 \\
\end{tabular} & \begin{tabular}{|l|}
$\operatorname{Rp} \quad 89,180$ \\
\end{tabular} & \begin{tabular}{|l|}
$\operatorname{Rp} \quad 99,691$ \\
\end{tabular} & Rp 110,436 & Rp 121,423 & \begin{tabular}{|l|} 
Rp 132,664 \\
\end{tabular} & Rp 144,169 & Rp 155,951 & $\mathrm{Rp}$ & 168,022 \\
\hline Pajak & $\mathrm{Rp}$ & 24,087 & Rp $\quad 27,612$ & Rp 31,213 & Rp 34,892 & Rp 38,653 & Rp 42,498 & Rp $\quad 46,432$ & Rp $\quad 50,459$ & Rp 54,583 & $\mathrm{Rp}$ & 58,808 \\
\hline LABA BERSIH & $\mathrm{Rp}$ & 44,732 & \begin{tabular}{|l|}
$\operatorname{Rp} 51,280$ \\
\end{tabular} & 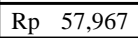 & 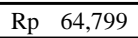 & 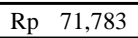 & 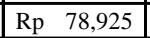 & $\begin{array}{|ll|}\operatorname{Rp} \quad 86,231 \\
\end{array}$ & Rp 93,710 & Rp 101,368 & $\mathrm{Rp}$ & 109,215 \\
\hline \begin{tabular}{|l|} 
Ak. Laba Bersih \\
\end{tabular} & $\mathbf{R p}$ & 44,732 & \begin{tabular}{|l|} 
Rp 96,012 \\
\end{tabular} & \begin{tabular}{|l|} 
Rp 153,979 \\
\end{tabular} & \begin{tabular}{|l|} 
Rp 218,779 \\
\end{tabular} & Rp 290,562 & \begin{tabular}{|l|} 
Rp 369,487 \\
\end{tabular} & \begin{tabular}{|l|}
$\operatorname{Rp} 455,718$ \\
\end{tabular} & \begin{tabular}{|l|} 
Rp 549,429 \\
\end{tabular} & \begin{tabular}{|l|} 
Rp 650,797 \\
\end{tabular} & $\mathbf{R p}$ & 760,011 \\
\hline
\end{tabular}




\section{Moderat: penjualan naik 3\% dan biaya naik 1\% (000)}

\begin{tabular}{|c|c|c|c|c|c|c|c|c|c|c|c|c|c|}
\hline TAHUN & & 1 & 2 & 3 & 4 & 5 & 6 & 7 & 8 & \multicolumn{2}{|r|}{9} & \multicolumn{2}{|r|}{10} \\
\hline TOTAL PENJUALAN & $\mathrm{Rp}$ & 779,724 & Rp 803,116 & Rp 827,209 & $\operatorname{Rp~} 852,025$ & $\operatorname{Rp} 877,586$ & Rp 903,914 & Rp 931,031 & Rp 958,962 & $\mathrm{Rp}$ & 987,731 & $\mathrm{Rp}$ & $1,017,363$ \\
\hline \multirow{2}{*}{\multicolumn{14}{|c|}{$\begin{array}{l}\text { BIAYA OPERASI } \\
\text { 1. BAHAN BAKU }\end{array}$}} \\
\hline & & & & & & & & & & & & & \\
\hline Bahan Bakar (Solar) & $\mathrm{Rp}$ & 125,832 & Rp 127,090 & Rp 128,361 & Rp 129,645 & Rp 130,941 & Rp 132,251 & Rp 133,573 & Rp 134,909 & $\mathrm{Rp}$ & 136,258 & $\mathrm{Rp}$ & 137,621 \\
\hline \multirow{2}{*}{\multicolumn{14}{|c|}{\begin{tabular}{l|ll|ll|ll|ll|ll|ll|ll|l}
6,420 & $\mathrm{Rp}$ & 6,548 & $\mathrm{Rp}$ & 6,679 & $\mathrm{Rp}$ & 6,813 & $\mathrm{Rp}$ & 6,949 & $\mathrm{Rp}$ & 7,088 & $\mathrm{Rp}$ & 7,230 & $\mathrm{Rp}$ & 7,375 & $\mathrm{Rp}$
\end{tabular}}} \\
\hline & & & & & & & & & & & & & \\
\hline Makan-minum & $\mathrm{Rp}$ & 8,418 & $\mathrm{Rp} \quad 8,586$ & $\mathrm{Rp} \quad 8,758$ & Rp $\quad 8,933$ & $\mathrm{Rp} \quad 9,112$ & $\operatorname{Rp} \quad 9,294$ & Rp $\quad 9,480$ & Rp $\quad 9,670$ & $\mathrm{Rp}$ & 9,863 & $\mathrm{Rp}$ & 10,060 \\
\hline Rokok & $\mathrm{Rp}$ & 48,150 & Rp 48,632 & Rp 49,118 & Rp 49,609 & $\mathrm{Rp} 50,105$ & Rp 50,606 & $\operatorname{Rp} 51,112$ & $\mathrm{Rp} \quad 51,623$ & $\mathrm{Rp}$ & 52,140 & $\mathrm{Rp}$ & 52,661 \\
\hline \multicolumn{14}{|l|}{ 3. REPARASI DAN PERAWATAN AKTIVA } \\
\hline Pemeliharaan Mesin & $\mathrm{Rp}$ & 120,000 & Rp 121,200 & Rp 122,412 & Rp 123,636 & Rp 124,872 & Rp 126,121 & Rp 127,382 & Rp 128,656 & $\mathrm{Rp}$ & 129,943 & $\mathrm{Rp}$ & 131,242 \\
\hline Pemeliharaan Bagan dan Perahu & $\mathrm{Rp}$ & 24,000 & Rp 24,240 & Rp 24,482 & Rp 24,727 & Rp 24,974 & Rp 25,224 & Rp 25,476 & $\operatorname{Rp} \quad 25,731$ & $\mathrm{Rp}$ & 25,989 & $\mathrm{Rp}$ & 26,248 \\
\hline Jumlah Biaya Operasi & $\mathrm{Rp}$ & 332,820 & Rp 336,297 & Rp 339,811 & Rp 343,363 & Rp 346,954 & Rp 350,585 & Rp 354,254 & Rp 357,964 & $\mathrm{Rp}$ & 361,714 & $\mathrm{Rp}$ & 365,505 \\
\hline \multicolumn{14}{|l|}{ 4. BIAYA TENAGA KERJA } \\
\hline Tenaga Tetap & $\mathrm{Rp}$ & 240,000 & Rp 242,400 & Rp 244,824 & Rp 247,272 & Rp 249,745 & Rp 252,242 & Rp 254,765 & Rp 257,312 & $\mathrm{Rp}$ & 259,886 & $\mathrm{Rp}$ & 262,484 \\
\hline Tenaga Tidak tetap & $\mathrm{Rp}$ & 6,000 & $\mathrm{Rp} \quad 6,060$ & $\mathrm{Rp} \quad 6,121$ & Rp $\quad 6,182$ & $\mathrm{Rp} \quad 6,244$ & $\mathrm{Rp} \quad 6,306$ & Rp $\quad 6,369$ & $\operatorname{Rp} \quad 6,433$ & $\mathrm{Rp}$ & 6,497 & $\mathrm{Rp}$ & 6,562 \\
\hline 5. BIAYA ADMINISTRSI \& PENJUALAN & $\mathrm{Rp}$ & 12,300 & Rp $\quad 12,423$ & $\operatorname{Rp} 12,547$ & Rp 12,673 & Rp 12,799 & $\mathrm{Rp} \quad 12,927$ & Rp 13,057 & Rp 13,187 & $\mathrm{Rp}$ & 13,319 & $\mathrm{Rp}$ & 13,452 \\
\hline TOTAL BIAYA OPERASI & $\mathrm{Rp}$ & 591,120 & Rp 597,180 & Rp 603,303 & Rp 609,490 & Rp 615,742 & Rp 622,061 & Rp 628,445 & Rp 634,897 & $\mathrm{Rp}$ & 641,416 & $\mathrm{Rp}$ & 648,004 \\
\hline LABA KOTOR & $\mathrm{Rp}$ & 188,604 & Rp 205,936 & Rp 223,906 & $\operatorname{Rp~242,535}$ & $\operatorname{Rp} 261,844$ & Rp 281,853 & Rp 302,586 & Rp 324,066 & $\mathrm{Rp}$ & 346,315 & $\mathrm{Rp}$ & 369,359 \\
\hline Biaya Peny. Da & $\mathrm{Rp}$ & 89,785 & Rp 89,785 & Rp 89,785 & Rp 89,785 & Rp $\quad 89,785$ & Rp 89,785 & Rp 89,785 & Rp $\quad 89,785$ & $\mathrm{Rp}$ & 89,785 & $\mathrm{Rp}$ & 89,785 \\
\hline Biaya Bunga & $\mathrm{Rp}$ & 30,000 & Rp 27,724 & Rp 25,311 & Rp $\quad 22,754$ & Rp 20,043 & $\mathrm{Rp} \quad 17,170$ & Rp $\quad 14,124$ & Rp $\quad 10,895$ & $\mathrm{Rp}$ & 7,473 & $\mathrm{Rp}$ & 3,845 \\
\hline LABA SEBELUM PAJAK & $\mathrm{Rp}$ & 68,819 & $\begin{array}{ll}\mathrm{Rp} & 88,427 \\
\end{array}$ & Rp 108,810 & \begin{tabular}{|l|} 
Rp 129,996 \\
\end{tabular} & Rp 152,016 & Rp 174,899 & \begin{tabular}{|l|} 
Rp 198,677 \\
\end{tabular} & $\operatorname{Rp} 223,385$ & $\mathrm{Rp}$ & 249,057 & $\mathrm{Rp}$ & 275,729 \\
\hline Ak. Laba Terkena Pajak & $\mathrm{Rp}$ & 68,819 & $\begin{array}{ll}\mathrm{Rp} & 88,427\end{array}$ & Rp 108,810 & \begin{tabular}{|l|} 
Rp 129,996 \\
\end{tabular} & Rp 152,016 & Rp 174,899 & \begin{tabular}{|l|} 
Rp 198,677 \\
\end{tabular} & Rp 223,385 & $\mathrm{Rp}$ & 249,057 & $\mathrm{Rp}$ & 275,729 \\
\hline Pajak & $\mathrm{Rp}$ & 24,087 & Rp 30,950 & Rp 38,084 & Rp 45,499 & Rp 53,205 & Rp 61,214 & Rp $\quad 69,537$ & Rp 78,185 & $\mathrm{Rp}$ & 87,170 & $\mathrm{Rp}$ & 96,505 \\
\hline LABA BERSIH & $\mathrm{Rp}$ & 44,732 & $\begin{array}{ll}\text { Rp } \quad 57,478 \\
\end{array}$ & Rp 70,727 & \begin{tabular}{|l|}
$\operatorname{Rp} \quad 84,498$ \\
\end{tabular} & 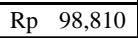 & Rp 113,684 & \begin{tabular}{|l|} 
Rp 129,140 \\
\end{tabular} & Rp 145,200 & $\mathrm{Rp}$ & 161,887 & $\mathrm{Rp}$ & 179,224 \\
\hline Ak. Laba Bersih & $\mathbf{R p}$ & 44,732 & Rp 102,210 & Rp 172,937 & \begin{tabular}{|l|} 
Rp 257,434 \\
\end{tabular} & Rp 356,244 & Rp 469,928 & \begin{tabular}{|l|} 
Rp 599,069 \\
\end{tabular} & \begin{tabular}{|l|} 
Rp 744,269 \\
\end{tabular} & Rp & 906,156 & & $1,085,380$ \\
\hline
\end{tabular}


Optimis: Penjualan naik $5 \%$ dan biaya naik $2 \%(000)$

\begin{tabular}{|c|c|c|c|c|c|c|c|c|c|c|c|c|c|c|c|c|}
\hline \multirow{2}{*}{\begin{tabular}{|l|} 
TAHUN \\
TOTAL PENJUALAN \\
\end{tabular}} & \multicolumn{2}{|r|}{1} & 2 & 3 & 4 & 5 & \multicolumn{2}{|r|}{6} & \multicolumn{2}{|r|}{7} & \multicolumn{2}{|r|}{8} & \multicolumn{2}{|r|}{9} & \multicolumn{2}{|r|}{10} \\
\hline & $\mathrm{Rp}$ & 779,724 & Rp 818,710 & Rp 859,646 & \begin{tabular}{|l|} 
Rp 902,628 \\
\end{tabular} & Rp 947,759 & & 995,147 & & $1,044,905$ & $\mathrm{Rp} 1$ & ,097,150 & Rp 1 & $1,152,007$ & Rp 1, & ,209,608 \\
\hline & & & & & & & & & & & & & & & & \\
\hline 1. BAHAN BAKU & & & & & & & & & & & & & & & & \\
\hline Bahan Bakar (Solar) & $\mathrm{Rp}$ & 125,832 & Rp 128,349 & Rp 130,916 & Rp 133,534 & Rp 136,205 & $\mathrm{Rp}$ & 138,929 & $\mathrm{Rp}$ & 141,707 & $\mathrm{Rp}$ & 144,541 & $\mathrm{Rp}$ & 147,432 & $\mathrm{Rp}$ & 150,381 \\
\hline $\begin{array}{l}\text { Umpan Mancing } \\
\text { OVERHEAD PABRIK }\end{array}$ & $\mathrm{Rp}$ & 6,420 & $\operatorname{Rp} \quad 6,548$ & Rp $\quad 6,679$ & $\mathrm{Rp} \quad 6,813$ & Rp $\quad 6,949$ & $\mathrm{Rp}$ & 7,088 & $\mathrm{Rp}$ & 7,230 & $\mathrm{Rp}$ & 7,375 & $\mathrm{Rp}$ & 7,522 & $\mathrm{Rp}$ & 7,672 \\
\hline Makan-minum & $\mathrm{Rp}$ & 8,418 & $\mathrm{Rp} \quad 8,586$ & Rp $\quad 8,758$ & $\mathrm{Rp} \quad 8,933$ & $\mathrm{Rp} \quad 9,112$ & $\mathrm{Rp}$ & 9,294 & $\mathrm{Rp}$ & 9,480 & $\mathrm{Rp}$ & 9,670 & $\mathrm{Rp}$ & 9,863 & $\mathrm{Rp}$ & 10,060 \\
\hline Rokok & $\mathrm{Rp}$ & 48,150 & Rp 49,113 & Rp 50,095 & Rp 51,097 & Rp 52,119 & $\mathrm{Rp}$ & 53,161 & $\mathrm{Rp}$ & 54,225 & $\mathrm{Rp}$ & 55,309 & $\mathrm{Rp}$ & 56,415 & $\mathrm{Rp}$ & 57,544 \\
\hline 3. REPARASI DAN PERAWATAN & & & & & & & & & & & & & & & & \\
\hline Pemeliharaan Mesin & $\mathrm{Rp}$ & 120,000 & Rp 122,400 & Rp 124,848 & Rp 127,345 & Rp 129,892 & $\mathrm{Rp}$ & 132,490 & $\mathrm{Rp}$ & 135,139 & $\mathrm{Rp}$ & 137,842 & $\mathrm{Rp}$ & 140,599 & $\mathrm{Rp}$ & 143,411 \\
\hline Pemeliharaan Bagan dan & $\mathrm{Rp}$ & 24,000 & $\operatorname{Rp} \quad 24,480$ & Rp 24,970 & $\mathrm{Rp} \quad 25,469$ & Rp 25,978 & $\mathrm{Rp}$ & 26,498 & $\mathrm{Rp}$ & 27,028 & $\mathrm{Rp}$ & 27,568 & $\mathrm{Rp}$ & 28,120 & $\mathrm{Rp}$ & 28,682 \\
\hline Jumlah Biaya Operasi & $\mathrm{Rp}$ & 332,820 & Rp 339,476 & \begin{tabular}{|l|} 
Rp 346,266 \\
\end{tabular} & \begin{tabular}{|l|}
$\operatorname{Rp} 353,191$ \\
\end{tabular} & Rp 360,255 & $\mathrm{Rp}$ & 367,460 & $\mathrm{Rp}$ & 374,809 & $\mathrm{Rp}$ & 382,306 & $\mathrm{Rp}$ & 389,952 & $\mathrm{Rp}$ & 397,751 \\
\hline 4. BIAYA TENAGA KERJ $F$ & & & & & & & & & & & & & & & & \\
\hline Tenaga Tetap & $\mathrm{Rp}$ & 240,000 & Rp 244,800 & Rp 249,696 & Rp 254,690 & Rp 259,784 & $\mathrm{Rp}$ & 264,979 & $\mathrm{Rp}$ & 270,279 & $\mathrm{Rp}$ & 275,685 & $\mathrm{Rp}$ & 281,198 & $\mathrm{Rp}$ & 286,822 \\
\hline Tenaga Tidak tetap & $p$ & 6,000 & Rp $\quad 6,120$ & Rp $\quad 6,242$ & $\mathrm{Rp} \quad 6,367$ & $\mathrm{Rp} \quad 6,495$ & $\mathrm{Rp}$ & 6,624 & $\mathrm{Rp}$ & 6,757 & $\mathrm{Rp}$ & 6,892 & $\mathrm{Rp}$ & 7,030 & $\mathrm{Rp}$ & 7,171 \\
\hline 5. BIAYA ADMINISTRSI \& PE & P & 12,300 & Rp $\quad 12,546$ & Rp $\quad 12,797$ & Rp 13,053 & Rp 13,314 & $\mathrm{Rp}$ & 13,580 & $\mathrm{Rp}$ & 13,852 & $\mathrm{Rp}$ & 14,129 & $\mathrm{Rp}$ & 14,411 & $\mathrm{Rp}$ & 14,700 \\
\hline TOTAL BIAYA OPERASI & $\mathrm{Rp}$ & 591,120 & Rp 602,942 & Rp 615,001 & \begin{tabular}{|l|}
$\operatorname{Rp} 627,301$ \\
\end{tabular} & Rp 639,847 & $\mathrm{Rp}$ & 652,644 & $\mathrm{Rp}$ & 665,697 & $\mathrm{Rp}$ & 679,011 & $\mathrm{Rp}$ & 692,591 & $\mathrm{Rp}$ & 706,443 \\
\hline LABA KOTOR & $\mathrm{Rp}$ & 188,604 & Rp 215,768 & Rp 244,644 & \begin{tabular}{|l|}
$\operatorname{Rp} 275,327$ \\
\end{tabular} & $\operatorname{Rp~307,912}$ & $\mathrm{Rp}$ & 342,503 & $\mathrm{Rp}$ & 379,208 & $\mathrm{Rp}$ & 418,139 & $\mathrm{Rp}$ & 459,416 & $\mathrm{Rp}$ & 503,165 \\
\hline Biaya Peny. Dan Amortisasi & & 89,785 & Rp 89,785 & Rp 89,785 & Rp 89,785 & Rp 89,785 & $\mathrm{Rp}$ & 89,785 & $\mathrm{Rp}$ & 89,785 & $\mathrm{Rp}$ & 89,785 & $\mathrm{Rp}$ & 89,785 & $\mathrm{Rp}$ & 89,785 \\
\hline Biaya Bunga & $\mathrm{Rp}$ & 30,000 & Rp $\quad 27,724$ & Rp 25,311 & Rp 22,754 & Rp 20,043 & $\mathrm{Rp}$ & 17,170 & $\mathrm{Rp}$ & 14,124 & $\mathrm{Rp}$ & 10,895 & $\mathrm{Rp}$ & 7,473 & $\mathrm{Rp}$ & 3,845 \\
\hline LABA SE & $\mathrm{Rp}$ & 68,819 & Rp 98,259 & \begin{tabular}{|l|} 
Rp 129,548 \\
\end{tabular} & \begin{tabular}{|l|}
$\operatorname{Rp} 162,788$ \\
\end{tabular} & Rp 198,084 & $\mathrm{Rp}$ & 235,548 & $\mathrm{Rp}$ & 275,299 & $\mathrm{Rp}$ & 317,459 & $\mathrm{Rp}$ & 362,158 & $\mathrm{Rp}$ & 409,534 \\
\hline Ak. Laba Terkena Pajak & $\mathrm{Rp}$ & 68,819 & Rp 98,259 & Rp 129,548 & \begin{tabular}{|l|}
$\operatorname{Rp} 162,788$ \\
\end{tabular} & Rp 198,084 & $\mathrm{Rp}$ & 235,548 & $\mathrm{Rp}$ & 275,299 & Rp & 317,459 & $\mathrm{Rp}$ & 362,158 & $\mathrm{Rp}$ & 409,534 \\
\hline Pajak & $\mathrm{Rp}$ & 24,087 & Rp 34,391 & Rp 45,342 & $\operatorname{Rp} 56,976$ & $\mathrm{Rp} \quad 69,329$ & $\mathrm{Rp}$ & 82,442 & $\mathrm{Rp}$ & 96,355 & $\mathrm{Rp}$ & 111,111 & $\mathrm{Rp}$ & 126,755 & $\mathrm{Rp}$ & 143,337 \\
\hline LABA BERSIF & $P$ & 44,732 & $\begin{array}{ll}\text { Rp } \quad 63,868 \\
\end{array}$ & \begin{tabular}{|l|} 
Rp $\quad 84,206$ \\
\end{tabular} & \begin{tabular}{|l|} 
Rp 105,812 \\
\end{tabular} & Rp 128,755 & $\mathrm{Rp}$ & 153,106 & $\mathrm{Rp}$ & 178,944 & $\mathrm{Rp}$ & 206,348 & $\mathrm{Rp}$ & 235,403 & $\mathrm{Rp}$ & 266,197 \\
\hline Ak. Laba Bersih & Rp & 44,732 & Rp 108,601 & \begin{tabular}{|l|} 
Rp 192,807 \\
\end{tabular} & \begin{tabular}{|l|} 
Rp 298,619 \\
\end{tabular} & Rp 427,373 & $\mathbf{R p}$ & 580,480 & $\mathbf{R p}$ & 759,424 & $\mathbf{R p}$ & 965,772 & Rp 1 & $1,201,175$ & Rp 1, & $, 467,372$ \\
\hline
\end{tabular}

Pertumbuhan dan perkembangan didasarkan pada proyeksi yang pesimis $1 \%$ dengan kenaikan biaya $0 \%$, moderat $3 \%$ dengan kenaikan biaya $1 \%$, dan optimis 5\% dengan kenaikan biaya 2\%. Pada skenario pesimis laba bersih Rp760.011.000 sampai tahun ke sepuluh atau 12,8\% dari penjualan bersih. Pada skenario moderat laba bersih sampai tahun ke sepuluh adalah Rp1.085.380.000 dengan persentase 17,61\% dari penjualan. Keuntungan yang lebih besar ditunjukan pada skenario optimis yaitu laba bersih Rp1.467.372.000 dengan persentase 22\% dari penjualan bersih. 
Analisis Laporan Arus Kas

Pesimis: Penjualan naik $1 \%$ dan biaya tetap $(000)$

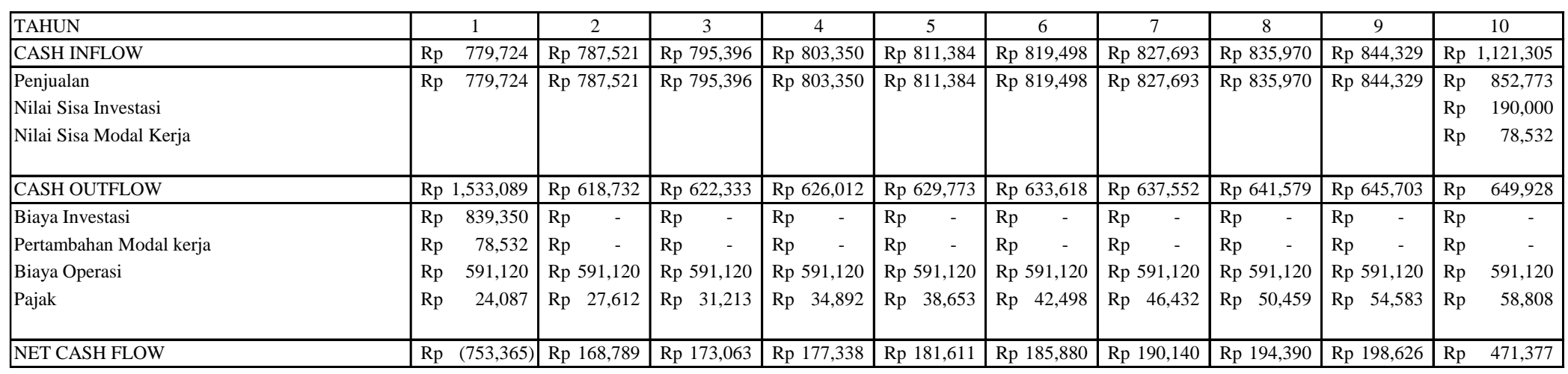

Moderat: Penjualan naik 3\% dan Biaya naik 1\% (000).

\begin{tabular}{|c|c|c|c|c|c|c|c|c|c|c|c|}
\hline TAHUN & 1 & 2 & 3 & 4 & 5 & 6 & 7 & 8 & & 9 & 10 \\
\hline CASH INFLOW & $\begin{array}{|ll|}\text { Rp } & 779,724 \\
\end{array}$ & $\operatorname{Rp~} 803,116$ & Rp 827,209 & Rp 852,025 & Rp 877,586 & Rp 903,914 & Rp 931,031 & Rp 958,962 & $\mathrm{Rp}$ & 987,731 & Rp $1,289,16$ \\
\hline \begin{tabular}{|l|} 
Penjualan \\
Nilai Sisa Investasi \\
Nilai Sisa Modal Kerja
\end{tabular} & $\begin{array}{ll}\mathrm{Rp} & 779,724\end{array}$ & Rp 803,116 & Rp 827,209 & Rp 852,025 & Rp 877,586 & Rp 903,914 & Rp 931,031 & Rp 958,962 & $\mathrm{Rp}$ & 987,731 & $\begin{array}{rr}\text { Rp } & 1,017,36 \\
\text { Rp } & 190,00 \\
\text { Rp } & 81,80\end{array}$ \\
\hline CASH OUTFLOW & \begin{tabular}{|l|} 
Rp $1,533,089$ \\
\end{tabular} & \begin{tabular}{|l|} 
Rp 628,477 \\
\end{tabular} & Rp 641,738 & Rp 655,344 & Rp 669,307 & $\operatorname{Rp} 683,638$ & \begin{tabular}{|l|}
$\operatorname{Rp} 698,349$ \\
\end{tabular} & Rp 713,452 & $\mathrm{Rp}$ & 728,961 & $\begin{array}{ll}\mathrm{Rp} & 744,88 \varepsilon \\
\end{array}$ \\
\hline Biaya Investasi & \begin{tabular}{|ll}
$\mathrm{Rp}$ & 839,350 \\
\end{tabular} & $\mathrm{Rp}$ & $\mathrm{Rp}$ & & & & & & $\mathrm{Rp}$ & - & $\mathrm{Rp}$ \\
\hline Pertambahan Modal kerja & 78,532 & 348 & 351 & 355 & 359 & 363 & 367 & 371 & $\mathrm{Rp}$ & 375 & $\mathrm{Rp}$ \\
\hline Biaya Operasi & Rp 591,120 & Rp 597,180 & Rp 603,303 & Rp 609,490 & Rp 615,742 & $\operatorname{Rp} 622,061$ & Rp 628,445 & Rp 634,897 & $\mathrm{Rp}$ & 641,416 & $\mathrm{Rp} \quad 648,00$ \\
\hline Pajak & 24,087 & Rp 30,950 & Rp 38,084 & Rp $\quad 45,499$ & Rp 53,205 & $\operatorname{Rp} \quad 61,214$ & Rp 69,537 & $\mathrm{Rp} \quad 78,185$ & $\mathrm{Rp}$ & 87,170 & 96,50 \\
\hline NET CASH FLOW & \begin{tabular}{|ll}
$\operatorname{Rp} \quad(753,365)$ \\
\end{tabular} & Rp 174,639 & $\operatorname{Rp} 185,471$ & Rp 196,681 & Rp 208,279 & Rp 220,276 & $\operatorname{Rp} 232,682$ & Rp 245,510 & $\mathrm{Rp}$ & 258,770 & $\begin{array}{ll}\mathrm{Rp} & 544,27 \\
\end{array}$ \\
\hline
\end{tabular}

Positif: Penjualan naik 5\% dan biaya naik 3\% (000) 


\begin{tabular}{|c|c|c|c|c|c|c|c|c|c|c|c|c|c|}
\hline TAHUN & 1 & 2 & 3 & 4 & 5 & 6 & & 7 & & 8 & & 9 & 10 \\
\hline \begin{tabular}{|l} 
CASH INFLOW \\
\end{tabular} & $\begin{array}{ll}\text { Rp } & 779,724 \\
\end{array}$ & \begin{tabular}{|l|}
$\operatorname{Rp} 818,710$ \\
\end{tabular} & Rp 859,646 & Rp 902,628 & \begin{tabular}{|l|} 
Rp 947,759 \\
\end{tabular} & Rp 995,147 & $\mathrm{Rp}$ & $1,044,905$ & $\mathrm{Rp}$ & $1,097,150$ & $\mathrm{Rp}$ & $1,152,007$ & Rp $1,484,633$ \\
\hline \begin{tabular}{|l|} 
Penjualan \\
Nilai Sisa Investasi \\
Nilai Sisa Modal Kerja
\end{tabular} & $\begin{array}{ll}\mathrm{Rp} & 779,724 \\
\end{array}$ & \begin{tabular}{|l|}
$\operatorname{Rp} 818,710$ \\
\end{tabular} & Rp 859,646 & Rp 902,628 & \begin{tabular}{|l} 
Rp 947,759 \\
\end{tabular} & Rp 995,147 & $\mathrm{Rp}$ & $1,044,905$ & $\mathrm{Rp}$ & $1,097,150$ & $\mathrm{Rp}$ & $\overline{1,152,007}$ & $\begin{array}{lr}\text { Rp } & 1,209,608 \\
\text { Rp } & 190,000 \\
\text { Rp } & 85,025\end{array}$ \\
\hline \begin{tabular}{|l} 
CASH OUTFLOW \\
\end{tabular} & Rp 1,533,089 & \begin{tabular}{|l|}
$\operatorname{Rp} 637,999$ \\
\end{tabular} & $\operatorname{Rp} 661,022$ & Rp 684,970 & \begin{tabular}{|l|}
$\operatorname{Rp} 709,883$ \\
\end{tabular} & $\operatorname{Rp} 735,807$ & $\mathrm{Rp}$ & 762,787 & $\mathrm{Rp}$ & 790,871 & $\mathrm{Rp}$ & 820,111 & $\begin{array}{ll}\mathrm{Rp} & 850,560\end{array}$ \\
\hline Biaya Investasi & $\begin{array}{ll}\mathrm{Rp} & 839,350\end{array}$ & $\mathrm{Rp}$ & $\mathrm{Rp}$ & $\mathrm{Rp}$ & & $\mathrm{Rp}$ & $\mathrm{Rp}$ & - & $\mathrm{Rp}$ & - & $\mathrm{Rp}$ & - & $\mathrm{Rp}$ \\
\hline Pertambahan Modal kerja & 78,532 & 666 & 679 & 693 & 706 & 721 & $\mathrm{Rp}$ & 735 & $\mathrm{Rp}$ & 750 & $\mathrm{Rp}$ & 765 & $\mathrm{Rp}$ \\
\hline Biaya Operasi & Rp $\quad 591,120$ & Rp 602,942 & Rp 615,001 & Rp 627,301 & Rp 639,847 & Rp 652,644 & $\mathrm{Rp}$ & 665,697 & $\mathrm{Rp}$ & 679,011 & $\mathrm{Rp}$ & 692,591 & Rp $\quad 706,443$ \\
\hline Pajak & 24,087 & Rp 34,391 & Rp 45,342 & Rp 56,976 & Rp $\quad 69,329$ & $\mathrm{Rp} \quad 82,442$ & $\mathrm{Rp}$ & 96,355 & $\mathrm{Rp}$ & 111,111 & $\mathrm{Rp}$ & 126,755 & Rp 143,337 \\
\hline \begin{tabular}{|l} 
NET CASH FLOW \\
\end{tabular} & $\begin{array}{ll}\operatorname{Rp} & (753,365) \\
\end{array}$ & \begin{tabular}{|l|}
$\operatorname{Rp} 180,712$ \\
\end{tabular} & Rp 198,624 & Rp 217,658 & \begin{tabular}{|l|}
$\operatorname{Rp} 237,876$ \\
\end{tabular} & Rp 259,341 & $\mathrm{Rp}$ & 282,118 & $\mathrm{Rp}$ & 306,279 & $\mathrm{Rp}$ & 331,896 & $\begin{array}{ll}\mathrm{Rp} & 634,073 \\
\end{array}$ \\
\hline
\end{tabular}

Laporan arus kas di setiap proyeksi memperlihatkan kenaikan dan pertumbuhan kas dengan nilai sisa investasi Rp190.000.000 dan nilai sisa modal kerja Rp78.532.000 pada semua skenario. Pada tahun pertama semua skenario menunjukan jumlah arus kas dengan hasil kerugian yang sama yaitu -Rp 753.365.000. Pada skenario pesimis, saldo kas pada tahun ke 10 sebesar Rp471.377.000, pada skenario moderat saldo kas sebesar Rp544,275.000 pada tahun kesepuluh, dan pada skenario optimis Rp634.073.000 pada tahun kesepuluh.

\section{Kriteria Penilaian Investasi}

\begin{tabular}{|c|c|c|c|c|c|}
\hline No & Alat Ukur & Skenario & Standar & Hasil Pengukuran & Keterangan \\
\hline \multirow{3}{*}{1} & \multirow{3}{*}{$\begin{array}{l}\text { Net present } \\
\text { Value (NPV) }\end{array}$} & Pesimis & Nilai Positif & $\mathrm{Rp} \quad 184.841 .000$ & Layak \\
\hline & & Moderat & Nilai Positif & $\mathrm{Rp} \quad 308.216 .000$ & Layak \\
\hline & & Optimis & Nilai Positif & Rp $\quad 450.939 .000$ & Layak \\
\hline \multirow{3}{*}{2} & \multirow{3}{*}{$\begin{array}{l}\text { Internal Rate } \\
\text { of Return } \\
\text { (IRR) }\end{array}$} & Pesimis & $>$ OCC Riel & $21,02 \%$ & Layak \\
\hline & & Moderat & > OCC Riel & $24,69 \%$ & Layak \\
\hline & & Optimis & > OCC Riel & $28,42 \%$ & Layak \\
\hline \multirow{3}{*}{3} & \multirow[t]{3}{*}{$\begin{array}{l}\text { Paybak } \\
\text { Period (PP) }\end{array}$} & Pesimis & $\begin{array}{c}<\text { Umur } \\
\text { Ekonomis }\end{array}$ & 5 Tahun 3 Bulan & Layak \\
\hline & & Moderat & $\begin{array}{c}<\text { Umur } \\
\text { Ekonomis }\end{array}$ & 4 Tahun 11 Bulan & Layak \\
\hline & & Optimis & $\begin{array}{c}<\text { Umur } \\
\text { Ekonomis }\end{array}$ & 4 Tahun 7 Bulan & Layak \\
\hline 4 & Profitability & Pesimis & > Dari 1 & 1,4 & Layak \\
\hline
\end{tabular}




\begin{tabular}{|l|l|l|l|l|}
\multirow{3}{*}{ Index $(\mathrm{PI})$} & Moderat & $>$ Dari 1 & 1,8 & Layak \\
\cline { 2 - 5 } & Optimis & $>$ Dari 1 & 2,2 & Layak \\
\hline
\end{tabular}

Dari tabel di atas setiap kriteria penilaian dikatakanlayak untuk dijalankan pada setiap skenario dengan nilai NPV positif, Nilai IRR lebih besar dari $O C C$ riel (discount rate), PP yang lebih kecil dari umur investasi dan nilai PI yang lebih besar dari 1. sehingga investasi pembuatan bagan apung baru dapat direkomendasikan kepada para investor untuk dipertimbangkan.

Analisis Sensitivitas

\begin{tabular}{|c|c|c|c|c|c|}
\hline \multirow{2}{*}{ Keterangan } & \multirow{2}{*}{ Skenario } & \multicolumn{2}{|c|}{ NPV } & \multicolumn{2}{|c|}{ IRR } \\
\hline & & Layak & Tidak Layak & Layak & Tidak Layak \\
\hline \multirow[t]{3}{*}{ Harga Jual Turun 3\% Pertahun } & Pesimis & & $\operatorname{Rp}(83,802)$ & & $10.98 \%$ \\
\hline & Moderat & $\begin{array}{ll}\mathbf{R} & \mathbf{8 , 7 9 3}\end{array}$ & & $14.82 \%$ & \\
\hline & Optimis & Rp 117,157 & & $18.73 \%$ & \\
\hline \multirow[t]{3}{*}{ Harga Jual Turun 5\% Pertahun } & Pesimis & & $\operatorname{Rp}(239,609)$ & & $2.98 \%$ \\
\hline & Moderat & & $\operatorname{Rp}(164,783)$ & & $7.10 \%$ \\
\hline & Optimis & & Rp $\quad(76,214)$ & & $11.31 \%$ \\
\hline \multirow[t]{3}{*}{ HPP Naik 10\% Pertahun } & Pesimis & & $\operatorname{Rp}(146,258)$ & & $8.55 \%$ \\
\hline & Moderat & Rp $\quad 48,432$ & & $16.17 \%$ & \\
\hline & Optimis & Rp 262,081 & & $22.61 \%$ & \\
\hline \multirow[t]{3}{*}{ HPP Naik $15 \%$ pertahun } & Pesimis & & $\operatorname{Rp}(341,913)$ & & $-4.15 \%$ \\
\hline & Moderat & & $\mathbf{R p}(147,223)$ & & $8.31 \%$ \\
\hline & Optimis & Rp 66,427 & & $16.81 \%$ & \\
\hline
\end{tabular}

Dari tabel di atas, dapat disimpulkan bahwa, jika harga jual turun lebih dari $5 \%$ pertahun, maka Nilai NPV dan IRR pada semua skenario dikatakan tidak layak. Namun jika harga jual ikan turun 3\% maka nilai NPV dan IRR pada skenario pesimis dan moderat adalah tidak layak sedangkan pada skenario optimis adalah layak. Jika biaya produksi naik hingga 15\% maka nilai hasil perhitungan NPV dan IRR dapat dikatakan tidak layak terkecuali pada skenario optimis nilai NPV bernilai positif dan nilai IRR melebihi nilai discount rate sehingga dapat direkomendasikan. Namun jika terjadi biaya produksi naik $10 \%$ pertahun maka nilai NPV dan IRR adalah layak pada skenario moderat dan optimis dan adalah tidak layak pada skenario pesimis. 


\section{KESIMPULAN}

1. Kelegalan usaha pada aspek hukum, strategi pemasaran (Marketing Mix) pada aspek pasar dan pemasaran, proses produksi pada aspek teknis/operasi, menyusun perencanaan, pengorganisasi, pelaksanaan dan melakukan pengawasan pada aspek manajemen, dampak positif pada aspek ekonomi dan sosial, serta tidak terdapat dampak negatif pada aspek AMDAL, maka kelayakan investasi pembuatan bagan apung pada setiap aspek di atas dapat dikatakan layak dan dapat diberikan rekomendasi.

2. Aspek keuangan. Berdasarkan analisis biaya dan keuntungan yang didapatkan dari bagan apung akumulasi laba bersih Rp 760.011.000 pada skenario pesimis, $\mathrm{Rp} \quad 1.085 .380 .000$ pada skenario moderat dan $\mathrm{Rp}$ 1.476.372.000 pada skenario optimis. Berdasarkan finansial usaha bagan apung diperoleh nilai NPV pada skenario pesimis: $\mathrm{Rp}$ 184.841.000, moderat: Rp 308.216.000 dan optimis: Rp 450.939.000. Nilai IRR pada skenario pesimis: $20,02 \%$, moderat: 24,69\%, dan optimis: 28,42\%. Pengembalian investasi atau PP pada skenario pesimis: 5 tahun 3 bulan, moderat: 4 tahun 11 bulan dan optimis 4 tahun 7 bulan, serta nilai PI pada skenario pesimis: 1,4 skenario moderat: 1,8 dan skenario optimis: 2,2\% sehingga hasil analisis pada semua aspek dikatakan layak.

3. Apabila terjadi penurunan harga ikan di atas $5 \%$ atau kenaikan biaya produksi hingga 15\% maka investasi menjadi tidak layak pada ketiga skenario. Hal ini disebabkan biasanya disebabkan oleh beberapa aspek yaitu, keadaan cuaca, posisi bulan, naiknya harga BBM dan hasil produksi yang lebih dari permintaan sehingga harga ikan menjadi turun.

\section{DAFTAR PUSTAKA}

Effendi, Reza. 2009. Jurnal. Analisis

Kelayakan Investasi Pendirian Pabrik Sepatu Olahraga di Indonesia. Depok: Universitas Indonesia.

Harahab, Nurdin, 2015. Evaluasi Proyek Usaha Perikanan. Malang: Universitas Brawijaya.
Husein, Umar. 2003. Studi Kelayakan Bisnis Edisi kedua. Jakarta: PT Gramedia Pustaka Utama.

Husnan, Suad dan Suwarsono Muhammad. 2000. Studi Kelayakan Investasi Proyek Edisi Keempat. Yogyakarta: UPP AMP YKPN.

Hironymus Jati,. 2008. Studi Kelayakan Bisnis. Kupang: Undana Press

Kasmir dan Jakfar. 2003. Studi Kelayakan Bisnis Edisi Revisi. Jakarta: PT. Kharisma PutraUtama.

Kasmir dan Jakfar.2010 Studi Kelayakan Investasi Edisi-2. Jakarta: PT Kharisma Putra Utama.

Kasmir dan Jakfar.2012 Studi Kelayakan Investasi Edisi-3. Jakarta: PT Kharisma Putra Utama.

Ningsih, Rahayu Septia. 2013. Jurnal: Analisis Kelayakan Finansial Keuangan Payang Jabur (Boat Seine) di Pelabuhan Perikanan Pantai Asemdoyong Kabupaten Pemalang. Pemalang: Universitas Diponegoro.

Sartono, Agus. 2012. Manajemen Keuangan Teori dan Aplikasi Edisi keempat. Yogyakarta: BPFE.

Simamora, Henry. 2012. Akuntansi Manajemen. Jakarta: Star Gate Publisher.

Sucipto, Agus. 2011. Studi Kelayakan Bisnis "Analisis Integrative dan Studi Kasus. Malang: UIN Maliki Press.

Sugiyono, 2014. Metode Penelitian Manajemen, Bandung, Alfabeta

Susilowati. Etty, dan Haruni Kurniawati. 2018. Jurnal. Analisis Kelayakan dan Sensitivitas (Studi Kasus Indutri Kecil Tempekopti Semanan, Kecematan Kalideres, Jakarta Barat). Universitas Budi Luhur: BISMA

Vivianie. Retno Demara, 2015. Jurnal: Analisis Kelayakan Investasi Usaha Berdasarkan Capital Budgeting Under Risk (Studi Pada Perusahaan Daerah Air Minum Kabupaten Banyuwangi). Malang: Universitas Brawijaya.

Warsika, Putu Dharma. 2009. Jurnal,Studi Kelayakan Investasi Bisnis Properti Cietar Riung Rangga. Bali: Universita Udayana. 
